\section{SERUM CALCIUM AND INORGANIC PHOSPHORUS IN TIGERS (PANTHERA TIGRIS) AND LEOPARD (PANTHERA PARDUS) KEPT IN CAPTIVITY}

\author{
S. Singh ${ }^{1}$, C. Singh ${ }^{2}$,A. Kumar ${ }^{3}$, K.K. Sinha ${ }^{4}$ and P.C. Mishra ${ }^{5}$ \\ ${ }^{1}$ J.A.R.O. Institute of Animal Health and production Patna, Bihar \\ 800014, India \\ ${ }^{2}$ Associate Professor, Department of Veterinary Physiology, Bihar \\ Veterinary College, Patna, Bihar 800014, India \\ ${ }^{3}$ T.V.O. Palkot, Gumala, Bihar, India \\ ${ }^{4}$ Veterinary Surgeon, Sanjay Gandhi Biological Park, Patna, Bihar \\ 800014, India \\ ${ }^{5}$ BSFDC and Ex-Director, Sanjay Gandhi Biological Park, Patna, \\ Bihar 800014, India
}

The study was conducted on adult, captive Tigers (Panthera tigris) and Leopard (Panthera pardus) of Sanjay Gandhi Zoological Park, Patna. They were fed once daily for six days a week. The quantity of feed provided to the animals and feeding schedule is presented in Table 1. Regular deworming was done with broad spectrum anthelmintics. The faecal samples of each animal were examined on three consecutive days and were found negative for parasitic infestation.

Single blood samples from each three male tigers (tigers), six female tigers (tigeress) and six female leopards (leopardess) were collected in winter season by restraining them is squeeze cage. Blood was collected either from dorsal branch of the medial saphenous vein in the hind leg at about the level of knee or from the recurrent tarsal vein in the hind leg. The serum calcium was estimated by the Clark and Collip method, while serum inorganic phosphorus was estimated by Fiske and Subbarow method as described by Kolmer et al (1969). The data were analysed for averages, standard error and analysis of variance as described by Snedecor and Cochran (1967).

The value of serum calcium and inorganic phosphorus have been presented in Table 2 . Nearly similar level of serum calcium and inorganic phosphorus was estimated among individual tigers, tigeress and leopardess. The calcium to phosphorus ratio in tigers, tigeress and leopardess was 2.91:1, 2.96:1 and $3.02: 1$ respectively.

The serum calcium value determined in tigers and leopardess was higher than the serum calcium reported in tigers, leopards and cheetah (Wallach \& Boever, 1983). In most of the mammals

Received 2 June 1999;

Accepted 30 September 1999 studied so far, the circulatory levels of calcium stands around 10 $\mathrm{mg} / \mathrm{dl}$ (Mc Donald, 1989). The level of serum calcium of tigers and leopardess of present experiment fall within the recommended range. Moreover, the serum calcium values of the experimental animals are comparable to the value recorded in male and female tigers and lion (Seal \& Makey, 1975), wild and captive mountain lion (Currier \& Russel, 1982).

The values of serum phosphorus in animals of our experiment was lower than the previous reports on tigers and lions (Seal \& Makey, 1975), wild and captive mountain lion (Currier \& Russel, 1982) Cheetah, Leopard, Bengal Tigers, African Lion and domestic cat (Wallach \& Boever, 1983). Alower value of serum calcium level than the value of serum calcium recorded in our experiment has also been reported in Bengal Tiger, Leopard and Cheetah (Wallach \& Boever, 1983). The serum calcium level in most of the species studied so far ranged between 8 and $13 \mathrm{mg} /$ dl. The calcium homeostasis is controlled by the intrinsic endocrine activity which mobilise the calcium from the G.I. tract whenever the calcium level in the circulation goes below the threshold value. At the same time, the intrinsic mechanism of the body remove the excess calcium from circulation and deposit it in the bones. In most of the mammals studied, the circulatory level of calcium stands around $10 \mathrm{mg} / \mathrm{dl}$. The persistant elevation of calcium above $12 \mathrm{mg} / \mathrm{dl}$ is considered as hypercalcaemia (Mc Donald, 1989). The level of serum calcium of the tigers and leopards of our experiment fall within the recommended range but towards higher value. The serum calcium of normal animals is near $10 \mathrm{mg} / \mathrm{dl}$ with some variation depending upon the analytical method employed as well as the age and diet of the animal. The serum calcium value of leopardess in our experiment is comparable to the value recorded in Cheetah, Leopard, Bengal Tiger, African Lion (Wallach \& Boever, 1983), male and female tiger, lion (Seal \& Makey, 1975) wild and captive mountain lion (Currier \& Russel, 1982), equine (Coles, 1974), dog (Kirk, 1989) and human being (Harper, 1975).

The serum phosphorus levels estimated in male and female tigers and leopardess of this experiment seems to be quiet identical. However, the value of serum phosphorus level in our experiment proved to be lower than the previous reports on Tigers and Lions (Seal \& Makey, 1975), wild and captive Mountain Lion (Currier \& Russel, 1982), Cheetah, Leopard, Bengal Tiger, African Lion and domestic cat (Wallach \& Boever, 1983). The higher value of calcium associated with slightly lower value of phosphorus in our experiment in comparision to the value of calcium and phosphorus recorded earlier on wild felids might be due to the differences in dietary composition in respect of calcium and phosphorus content made available to the animals of different experimental regimen. Besides the higher value of calcium (within the range) associated with lower serum phosphorus level may be due to consistently higher activity of intrinsic endocrine factor responsible for elevation of calcium level and decline of serum phosphorus level under certain managemental condition, that might have caused such condition of higher $\mathrm{Ca}: \mathrm{P}(2.91: 1$ to 3.02:1) ratio in our experimental animals 
in captivity. As it has been well documented that at the event of maintenance of serum calcium level towards $10 \mathrm{mg} / \mathrm{dl}$ or above and the blood phosphorus $4 \mathrm{mg} / \mathrm{dl}$ or in the lower normal range is due to maintenance of calcium at the higher level and inhibition of renal tubular reabsorption of phosphorus by the slightly elevated release of endocrine factor mainly parathormone by the parathyroid gland (Mc Donald, 1989). This intrinsic mechanism for the control of calcium and phosphorus level in circulation might be operating in our experimental wild felids kept in captivity which led to keep the serum calcium at a little higher but within the range by shifting the threshold of calcium towards higher value for the operation of internal endocrine factors responsible for calcium homeostasis.

It has been reported that the higher value of total protein in circulating blood is associated with elevated level (towards higher normal range) of calcium in circulation (Coles, 1974). In our experiment the total serum protein is higher than the total serum protein value of most of the felids which accounts for the higher physiological level of calcium in the circulation and agree well with the earlier statement (Coles, 1974). However, the calcium-phosphorus ratio of the individual animal (2.47:1 to 3 . $22: 1)$ as well as mean value (2.91:1 to $3.02: 1)$ is lower than the calcium phosphorus ratio (4.5:1) in equine (Coles, 1974) and similar to the values obtained in dog (Kirk, 1989; 2.2:1 to 3.4:1) and human being (Harper, 1975; 2.4:1 to 3:1).

\section{Acknowledgement}

Authors are thankful to the Dean-Cum-Principal, Bihar Veterinary College, Patna, for providing facilities for the study.

\section{References}

Coles, E.H. (1974). Veterinary Clinical Pathology 2nd ed; W B Saunder. Currier, M.J.P. and K. Russel (1982). Hematology and blood chemistry of the mountain lion (Felis concolor). Journal of Wildlife Diseases 18: 99-104

Harper, H.A. (1975). Review of Physiological chemistry 15th ed, Maruzen Asian edition, Lange Medical Publications Maruzen Company limited pp 427-430.

Kirk, R.W. (1989). Current Veterinary Therapy Small animal practice. 10th ed, W B Saunder.

Kolmer, J.A, E.H. Spaulding and H.W. Robinson (1969). Approved laboratory technic, 5th ed, (Indian ed).

Mc Donald, L.E. (1989). Veterinary Endocrinology and Reproduction. 4th ed, Lea \& Febiger.

Seal, U.S. and D.G. Makey (1975). Baseline laboratory data for captive native and exotic species. American Association of Zoo Veterinary and Seamak System.

Snedecor, G.W. and W.G. Cochran (1976). Statistical methods. 6th ed., Oxford \& IBH Publishing co.

Wallach, J.D. and W.J. Boever (1983). Diseases of Exotic Animals. W B Saunder.

Table 1. Prescribed carnivore diets provided to the animals during two different seasons

\begin{tabular}{lllll}
\hline Season & Feed & $\begin{array}{l}\text { Tiger } \\
\text { Male }\end{array}$ & Female & $\begin{array}{l}\text { Leopard } \\
\text { Female }\end{array}$ \\
\hline \multirow{2}{*}{ Winter } & Beef & $12 \mathrm{Kg}$ & $10 \mathrm{Kg}$ & $4.5 \mathrm{Kg}$ \\
& Egg & 02 & 02 & 02 \\
& Milk & 1 litre & $1 / 2$ litre & $1 / 4$ litre \\
& Water & Ad. lib & Ad. lib & Ad. lib \\
& & & & \\
Summer & Beef & $8 \mathrm{Kg}$ & $6 \mathrm{Kg}$ & $2.5 \mathrm{Kg}$ \\
& Milk & 1 litre & $1 / 2$ litre & $1 / 4$ litre \\
& Water & Ad. lib & Ad. lib & Ad. lib \\
\hline
\end{tabular}

Table 2. Serum calcium and inorganic phosphorus of tigers, and leopardess

\begin{tabular}{llll}
\hline & Male Tigers & Female Tigers & Leopardess \\
\hline $\begin{array}{l}\text { Serum calcium } \\
(\mathrm{mg} / \mathrm{dl})\end{array}$ & $\begin{array}{l}10.57+-0.07 \\
(10.40-10.70)\end{array}$ & $\begin{array}{l}10.87+-0.09 \\
(10.20-11.20)\end{array}$ & $\begin{array}{l}10.97+-0.49 \\
(8.40-11.80)\end{array}$ \\
$\begin{array}{l}\text { Serum inorganic } \\
\text { phosphorus } \\
(\mathrm{mg} / \mathrm{dl})\end{array}$ & $\begin{array}{l}3.63+-0.03 \\
(3.60-3.70)\end{array}$ & $\begin{array}{l}3.67+-0.05 \\
(3.50-3.30)\end{array}$ & $\begin{array}{l}3.63+-0.06 \\
(3.40-3.80)\end{array}$ \\
\hline
\end{tabular}

Figures in parenthesis shows no of animals. 